University of Wollongong

Research Online

Faculty of Business - Papers (Archive)

Faculty of Business and Law

2019

Money Demand in a Dollarized Economy: Evidence from Laos PDR

Phouphet Kyophilavong

National University of Laos

Gazi Uddin

Linkoping University

Muhammad Shahbaz

Montpellier Business School

Charles Harvie

University of Wollongong, charvie@uow.edu.au

Teerawat Charoenrat

Khon Kaen University, tc888@uowmail.edu.au

Follow this and additional works at: https://ro.uow.edu.au/buspapers

Part of the Business Commons

Research Online is the open access institutional repository for the University of Wollongong. For further information contact the UOW Library: research-pubs@uow.edu.au 


\title{
Money Demand in a Dollarized Economy: Evidence from Laos PDR
}

\author{
Abstract \\ This paper uses a time series perspective to examine the determinants and stability of the money \\ demand function in the case of Laos PDR. An autoregressive distributed lag bounds testing approach to \\ cointegration in the presence of structural breaks and Granger causality in a vector error correction \\ method framework are applied to data covering the period 1992:Q1 to 2013:Q4. The results indicate that \\ the money demand function is stable when exchange rate fluctuations are incorporated, and the causality \\ analysis reveals that there is a feedback effect between money demand and the exchange rate in the long \\ run. This implies that the exchange rate plays an important role in influencing money demand in the case \\ of a dollarized economy such as that of Laos. \\ Disciplines \\ Business \\ Publication Details \\ Kyophilavong, P., Uddin, G., Shahbaz, M., Harvie, C. \& Charoenrat, T. (2019). Money Demand in a Dollarized \\ Economy: Evidence from Laos PDR. Asian Economic Papers, 18 (1), 99-115.
}

This journal article is available at Research Online: https://ro.uow.edu.au/buspapers/1679 


\title{
Money Demand in a Dollarized Economy: Evidence from Laos PDR
}

\author{
Phouphet Kyophilavong \\ Faculty of Economics and Business Management \\ National University of Laos \\ PBOX 7322, FEB, NUoL, Dongdok, Vientiane \\ Lao PDR \\ Phouphetkyophilavong@gmail.com
}

\author{
Gazi Salah Uddin \\ Economics Division \\ Department of Management and Engineering \\ Linköping University \\ 58I 83, Linköping, Sweden \\ gazi.salah.uddin@liu.se
}

\section{Muhammad Shahbaz}

Energy and Sustainable Development

Montpellier Business School

34I 85 Montpellier, France

muhdshahbaz77@gmail.com

\author{
Charles Harvie \\ Faculty of Business \\ University of Wollongong \\ Building 40, Room 223 \\ Wollongong, NSW, Australia 2522 \\ charvie@uow.edu.au \\ Teerawat Charoenrat \\ Centre for Entrepreneurship, Innovation and SME Development \\ in the ASEAN Region (CEISDA) \\ Khon Kaen University \\ Nong Khai Campus, 43000, Thailand \\ tc888@uowmail.edu.au
}

\begin{abstract}
This paper uses a time series perspective to examine the determinants and stability of the money demand function in the case of Laos PDR. An autoregressive distributed lag bounds testing approach to cointegration in the presence of structural breaks and Granger causality in a vector error correction method framework are applied to data covering the period I992:Q I to 20 I3:Q4. The results indicate that the money demand function is stable when exchange rate fluctuations are incorporated, and the causality analysis reveals that there is a feedback effect between money demand and the exchange rate in the long run. This implies that the exchange rate plays an important role in influencing money demand in the case of a dollarized economy such as that of Laos.
\end{abstract}

\section{Introduction}

The success of monetary policy depends on whether a stable and, therefore, predictable relationship exists between money demand and its determinants (Gochoco-Bautista 2006; 
Ariff and Zarei 2018). Therefore, the estimation of money demand and its stability has gained the attention of academics, researchers, and policymakers in the area of monetary economics and applied macroeconomics. ${ }^{1}$ Earlier studies of the money demand function focused primarily on that for advanced economies, but more recently, the focus has shifted to emerging market and developing economies (e.g., Bahmani-Oskooee and Karacal [2006] for Turkey; Bahmani-Oskooee and Wang [2007] for China; Wu et al. [2005] for Taiwan; Tang [2007] for Southeast Asian countries). The findings of these have been inconclusive, ${ }^{2}$ however, and have generated several debatable issues. The first issue relates to the stability of the money demand function (MDF). ${ }^{3}$ Some studies find evidence of a stable money demand function (e.g., Wu et al. [2005] for Taiwan; Bahmani-Oskooee and Wang [2007] for China). Others find evidence of instability in money demand (e.g., Tang [2007] for Indonesia; Bahmani-Oskooee and Rehman [2005] for some ASEAN countries). Moreover, in earlier studies, the long-run parameters of the MDF, based on the Johansen cointegration approach (Johansen and Juselius 1990), might also be unstable (Akinlo 2006; BahmaniOskooee and Wang 2007).

A second issue focuses on the stability of the MDF in a dollarized economy. ${ }^{4}$ Several scholars argue that the MDF in a dollarized economy is highly unstable (Oomes and Ohnsorge 2005; Akinlo 2006). In contrast, some scholars argue that adding the exchange rate to the MDF makes money demand stable (Bahmani-Oskooee and Karacal 2006).

A third area of debate relates to the omission of important variables while estimating the MDF, which might cause bias estimation (Lutkepohl 1982; Baharumshah et al. 2009). Using only information on real income and interest rate variables might make the MDF unstable. Therefore, considering other variables, such as the influence of exchange rate movements and the foreign currency deposit interest rate on the MDF (Siddiki 2000) are key determinants in the context of a dollarized economy.

1 The studies of effectiveness of monetary policy during crisis include Gochoco-Bautista (2009) and Schnabl (2015).

2 Mundell (1963) was a pioneer in considering the role of the exchange rate in the demand for money function.

3 Stability of the MDF is an important issue for policymakers to facilitate predicting the relationship between money aggregates and its determinants in developed and developing countries (Judd and Scadding 1982; Ericsson 1998).

4 Dollarization is defined as the substitution of a foreign currency for domestic currency as a means of payment, unit of account, and store of value (e.g., Cuddington 1983; Menon 2008). Its adoption can lead to difficulties in the conduct of domestic monetary and exchange rate policies (Baliño et al. 1999; Berg and Borensztein 2000). It is unclear under what conditions would the advantages of dollarization (lower inflation, stable exchange rate, stable financial system) offset the disadvantages of dollarization (lack of an independent domestic monetary policy, etc.). 
Although previous research has been conducted on the MDF for Asian and other developing countries (e.g., Tang [2007] for Southeast Asian countries; Dekle and Pradhan [1999] for selected ASEAN countries; Chaisrisawatsuk et al. [2004] for selected ASEAN countries), there has been a lack of attention paid to transitional dollarized economies such as that of Laos. To the best of our knowledge, no study on the MDF of a transitional economy, specifically, Laos, has been conducted.

The focus of this study is on Laos, which is a transitional economy facing a highly dollarized economy. The ratio of foreign currency deposits to total bank deposits was about 50 percent in 2008 (Kyophilavong 2010). Having a dollarized economy makes the control of inflation through an independent monetary policy more difficult to implement effectively by a monetary authority. ${ }^{5}$ Laos faces financial problems in terms of a low level of financial deepening, an inability to control its domestic interest rate (Kyophilavong 2010), and macroeconomic instability, including large currency depreciation and high inflation rates. Therefore, in order to implement effective monetary policy, a study of the money demand function for Laos is important. Currently such a study has not been conducted. The aim of this study, therefore, is to investigate the MDF for Laos, determine its stability, and examine whether a long-run relationship exists between the MDF and its determinants.

This paper makes two contributions to the existing literature. First, it tests for MDF stability in the context of a dollarized economy, and in doing so, considers the role of the exchange rate and foreign interest rate in order to overcome the problem of omitted variables. Second, the autoregressive distributed lag (ARDL) bounds test approach in the presence of structure break arising in the series is applied to Laos' data. This study is a pioneering one, investigating the money demand function for the case of Laos, and, we hope, providing important implications for other transitional economies facing currency substitution.

The paper is structured as follows. Section 2 conducts a brief review of the Laos economy and highlights the current macroeconomic and policy environment. Section 3 discusses the operation of monetary and exchange rate policy. Section 4 outlines the money demand model used in this study and in Section 5 we present empirical results from this model. The main conclusions and policy recommendations from this paper are presented in Section 6.

\section{Current Lao economy situation}

Laos introduced reforms called the New Economic Mechanism in 1986 aimed at moving the country from a centrally planned to market oriented economy. Because of these reforms the country achieved high and stable economic growth averaging around 8 percent annually over the period 2006-15 (see Table 1). Except for the period of the 1997-98 Asian

5 Laos also experienced high inflation and an unstable exchange rate during the AFC. 
Table 1. Macroeconomic indicators

\begin{tabular}{|c|c|c|c|c|c|c|c|c|c|c|c|}
\hline Indicator & Unit & 2006 & 2007 & 2008 & 2009 & 2010 & 2011 & 2012 & 2013 & 2014 & 2015 \\
\hline GDP growth rate & $\%$ & 8.2 & 8.0 & 7.8 & 7.6 & 7.9 & 8.1 & 8.3 & 8.0 & 7.8 & 7.2 \\
\hline GDP per capita & US\$ & 745.0 & 838.8 & 935.0 & 966.3 & $1,087.5$ & $1,297.5$ & $1,445.4$ & $1,700.5$ & $1,754.9$ & $1,818.4$ \\
\hline $\begin{array}{l}\text { Inflation rate } \\
\text { (year-end) }\end{array}$ & $\%$ & 4.7 & 5.6 & 3.2 & 3.9 & 8.4 & 7.6 & 4.3 & 6.4 & 4.1 & 1.2 \\
\hline $\begin{array}{l}\text { Exchange rate } \\
\text { (kip per capita) }\end{array}$ & Kip & $10,767.0$ & $9,655.0$ & $9,341.0$ & $8,466.0$ & $8,066.0$ & $8,019.0$ & $7,982.0$ & $8,030.0$ & $8,069.3$ & $8,178.2$ \\
\hline $\begin{array}{l}\text { Broad money } \\
\text { growth }\end{array}$ & $\%$ & 7.7 & 30.1 & 38.7 & 18.3 & 16.7 & 28.7 & 31.0 & 17.0 & 16.6 & 23.7 \\
\hline $\begin{array}{l}\text { Budget deficit } \\
\text { (excluding } \\
\text { ODA) GDP }\end{array}$ & $\%$ & -7.4 & -6.7 & -6.9 & -6.9 & -3.2 & -1.7 & -0.5 & -5.6 & -4.2 & -4.7 \\
\hline $\begin{array}{c}\text { Current account } \\
\text { balance/GDP }\end{array}$ & $\%$ & -7.2 & 1.4 & 2.5 & 1.7 & -20.3 & -17.3 & -30.2 & -28.9 & -25.0 & -21.3 \\
\hline $\begin{array}{l}\text { Gross official } \\
\text { reserves }\end{array}$ & $\begin{array}{l}\text { In months } \\
\text { of } \\
\text { imports }\end{array}$ & 3.2 & 3.9 & 3.4 & 3.0 & 1.8 & 1.2 & 1.1 & 1.0 & 1.1 & 1.2 \\
\hline $\begin{array}{l}\text { External } \\
\text { debt/GDP }\end{array}$ & $\%$ & 79.8 & 65.7 & 60.5 & 54.5 & 48.1 & 46.7 & 47.7 & 48.3 & 48.5 & 48.7 \\
\hline
\end{tabular}

Source: Quarterly Statistics Review of Bank of Lao PDR (various issues).

Note: $O D A=$ official development assistance.

financial crisis (AFC), Laos has maintained low inflation and a stable exchange rate (Willett et al. 2004). Moreover, in the post-reform period the incidence of poverty declined significantly from 46 percent in 1993 to 23 percent in 2013 (LSB and WB 2014).

Despite the reform success, the country still faces many serious macroeconomic challenges. First, Laos faces chronic twin deficits in terms of its fiscal and trade balances. The country has experienced chronic trade deficits since the introduction of the New Economic Mechanism in 1986. Moreover, Laos is also facing high budgetary deficits amounting to 4.7 percent of GDP in 2015 (Table 1). Laos is facing a saving-investment imbalance. Domestic saving is relatively low, which is partially explained by the country's low-income level and the early stage of development of the banking and financial system (Toyoda and Kyophilavong 2005). Second, the country faces a high external debt burden. Even though the size of the external debt remains quite high, it has been in decline; external debt amounted to about 50 percent of GDP in 2015 (see Table 1). Third, the Laos economy depends heavily on its resource sector. The recent resources led to a decline in the production and exports of non-resources sectors such as agriculture and industry, thereby giving rise to a negative long-term impact known as Dutch disease (Kyophilavong and Toyoda 2008; Kyophilavong 2016).

The Lao PDR economy is also highly dollarized. People use foreign currencies widely as a means of payment, as a unit of account, and as a store of value. The high degree of dollarization makes it difficult for the authorities to control the money supply and makes the economy vulnerable to external shocks (Keovongvichith 2004; Kyophilavong 2010; Kyophilavong et al. 2017). Despite the benefits to the country from dollarization, there is also a cost to the Lao economy. Dollarization has hindered the ability of the monetary 
authority to conduct effective monetary and exchange rate policies. The government loses the benefit of seigniorage (Kyophilavong 2010). In addition, dollarization makes the economy more vulnerable to inflation and an increase in the volatility of the exchange rate (Baliño et al. 1999; Berg and Borensztein 2000; Menon 2006).

Dollarization in Laos has been one of the main historical sources of macroeconomic instability in the country (Kyophilavong 2010). Despite Laos having achieved improved macroeconomic stability since 2000, dollarization remains high. The ratio of foreign currency deposits to total deposits was about 50 percent in 2008 (Kyophilavong 2010) and reducing the extent of dollarization has become an important policy objective of the Bank of Lao PDR (hereafter BoL). Dollarization puts pressure on the government to maintain fiscal discipline but weakens the central bank's control over monetary policy. The Lao government also loses seigniorage, and it increases the potential for a banking crisis. Therefore, the monetary authority has tried to reduce the extent of dollarization by intervening in the exchange rate market, with the aim of promoting and campaigning for the greater use of the local currency (kip).

\section{Monetary and exchange rate policy in Laos}

After the 1975 communist revolution, Lao PDR established a centrally planned economy in which domestic prices, the exchange rate, as well as domestic and foreign trade, were strictly controlled by the state (Bourdet 1992). Before 1988, the State Bank conducted both central and commercial banking activities (Otani and Pham 1996). In 1990, the Central Bank component (BoL) was formally separated from the commercial banking component of the State Bank. The new BoL had its new roles and functions clearly defined, and this included responsibility for controlling monetary and financial developments and developing direct and indirect policy instruments. Price stability is the BoL's main policy goal, along with economic growth and poverty reduction (Kyophilavong 2010). The monetary policy instruments used include a mixture of direct and indirect tools with clear monetary channels and objectives (Kyophilavong 2010). To limit and target credit expansion, the BoL relies on direct instruments, including interest rate control on both lending and deposit rates. Indirect instruments such as reserve requirements and market operations, which were introduced in 1999, have been further developed since then.

The policy framework involves the implementation of monetary and exchange rate policies that establish floors for international reserves and ceilings for the net domestic assets of the central bank. The BoL conducts monetary policy by setting the annual growth rate of the money supply as an intermediate target, in line with the rate of economic growth and price stability. Under the BoL Law, its governance structure, all key monetary and exchange rate policies, including the BoL's action plans, must be approved by the government, and the instruments used must be approved by the BoL governor. 
The implementation of monetary policy in Lao PDR faces many challenges, however. There are four main reasons for the constraints it faces in the conduct of monetary policy. First, the Lao PDR economy is highly dollarized. As stated previously, more than 50 percent of bank deposits are in foreign currencies, mainly U.S. dollars. Therefore, the monetary authority cannot conduct policy effectively as it does not have complete control over the money supply (U.S. dollars). Second, the underdeveloped nature of domestic financial markets limits the effective implementation of monetary policies because the BoL has limited instruments available for conducting monetary policy. The implementation of monetary policy is also a lengthy and opaque decision-making process.

Before economic reform in 1986, Lao PDR had multiple exchange rates under a fixed exchange rate regime. The authorities began a dramatic reform and overhaul of the exchange regime in 1989 and adopted a managed-floating exchange rate regime (Otani and Pham 1996). Under this new regime, the BoL determined the daily reference rate for the kip against the dollar. This reference rate was modified from time to time in response to market conditions. Under this policy, the exchange rate has shown significant stability, although the exchange rate mechanism has some limitations. The range of exchange rates set for commercial banks is too small and thus limits the flexibility of the foreign exchange market, leading to a disincentive to develop the interbank market. Second, as the range of exchange rates set is too small, it creates an informal market for speculation (Kyophilavong 2010).To stabilize the value of the kip the BoL intervenes in the foreign exchange market to adjust the exchange rate by selling or buying foreign currencies. During the AFC, however, because of a lack of foreign reserves, the intervention was not effective. In addition, the central bank's lengthy decision-making process makes it difficult to implement exchange rate policies in the market (Kyophilavong 2010).

\section{The money demand model}

A long-run MDF depends on real economic transactions and opportunity cost that can be expressed as follows:

$$
M O N_{t}=a_{1}+a_{2} G D P t+a_{3} D R K t+a_{4} D R U S t+a_{5} E X C+a_{6} D D+u t,
$$

where $M O N_{t}$ is real money demand, GDP is real income, $D R K_{t}$ is the domestic currency deposit interest rate, $D R U S_{t}$ is the foreign currency deposit interest rate, $E X C_{t}$ is the nominal exchange rate (kip against US\$), and DD is a dummy variable. ${ }^{6}$ Following the existing literature, the estimated value of $a_{2}$ is expected to be positive. The coefficients capturing the opportunity cost of holding financial assets, $a_{3}$ and $a_{4}$, are expected to be negative. The coefficient capturing the effect of the nominal exchange rate on money demand $\left(a_{5}\right)$ could

6 The dummy variable could capture the structural break in the Lao economy based on the Perron unit-root test. 
be positive or negative. Arango and Nadiri (1981), for example, argue that the coefficient should be positive. The increase in exchange rate represents an appreciation of the foreign currency and a depreciation of the domestic currency. Holding foreign currency means that people believe that their wealth will decline if the foreign currency appreciates. This declining of wealth increases the demand for the domestic currency (or money). Contrary to this, Bahmani-Oskooee and Poorheydarian (1990) argue that the coefficient for the nominal exchange rate $\left(a_{5}\right)$ should be negative. The depreciation of the domestic currency would result in currency substitution towards the foreign currency and the domestic demand for money would decrease.

Our study uses quarterly data for Laos from 1992:Q1 to 2013:Q4 based on the availability of data. The data of money aggregate, exchange rate, and real GDP are obtained from International Financial Statistics of the International Monetary Fund. The foreign and domestic deposit interest rates are from Bank of Lao PDR. The money aggregate $M O N_{t}$ is defined as broad money (converted into the consumer price index). The foreign currency deposit interest rate (DRUSt) is percentage of interest rate of U.S. dollar deposit. All the variables except for two interest rates are variables converted to logarithmic transformations. ${ }^{7}$ Normally, the quarterly manufacturing production index (MPI) or industrial production index (IPI) are used as a proxy for real income. However, MPI and IPI data are not available in Laos. Therefore, we use an interpolation method to convert the annual data of the real GDP to its quarterly value. ${ }^{8}$

The empirical findings presented in this study are obtained through the ARDL approach (Pesaran and Shin 1999; Pesaran et al. 2001). Equation (1) identifies the long-run relationship among the variables in the traditional MDF. In order to implement the bounds testing approach to cointegration, equation (1) can be transformed into the conditional ARDL error correction models as follows:

$$
\begin{aligned}
\Delta \mathrm{MON}_{t}= & a_{0}+\sum_{i=1}^{p} b_{i} \Delta M O N_{t-i}+\sum_{i=1}^{p} c_{i} \Delta G D P_{t-i}+\sum_{i=1}^{p} d_{i} \Delta D R K_{t-i}+\sum_{i=1}^{p} e_{i} \Delta D R U S_{t-i} \\
& +\sum_{i=1}^{p} f_{i} \Delta E X C_{t-i} \\
\pi_{1} \text { MON }_{t-1} & +\pi_{2} G D P_{t-1}+\pi_{3} D R K_{t-1}+\pi_{4} D_{R U S} S_{t-1}+\pi_{5} E X C_{t-1}+\pi_{6} D D+u_{t},
\end{aligned}
$$

where $\Delta$ denotes the first difference of a variable, $D D_{t}$ is a dummy variable, $P$ is the maximum lag length, and $u_{t}$ is the usual white noise residual.

7 The log-linear specification provides efficient results as compared to simple specifications (Layson 1983).

8 This method has been used by Darrat and Al-Mutawaa (1996), Chaisrisawatsuk, Sharma, and Chowdhury (2004), and Kyophilavong et al. (2013). 
Before conducting the bounds test for cointegration, a unit-root test is conducted to ensure that the variables in the model are not integrated in terms of 2nd differences I (2), since the F-test might be biased if variables are stationary in 2nd differences (Outtara 2004). The Perron unit root test is then applied, which takes into action the existence of structural breaks (Perron 1997) because the ADF test (Dickey and Fuller 1979), DF-GLS test (Elliot et al. 1996), and Ng-Perron test (Ng and Perron 2001) provide biased results (Baum 2004).

The procedure for the bounds testing approach consists of two steps. The first step is to test for the existence of a long-run relationship among the variables. The second step is to estimate the coefficients of the long-run relationship if cointegration in the first step has been established. The F-test is used in the bounds test to identify the existence of a long-run relationship (Pesaran et al. 2001). The null hypothesis for the non-existence of a long-run relation denoted by $\left(\mathrm{F}_{\mathrm{MON}} \mathrm{MON}_{t} \mid G D P_{t}, D R K_{t}, D R U S_{t}, E X C_{t}\right)$ is $\left(\mathrm{H} 0: \pi_{1}=\pi_{2}=\pi_{3}=\pi_{4}=\pi_{5}=\right.$ 0 ) against (H1: $\pi_{1} \neq \pi_{2} \neq \pi_{3} \neq \pi_{4} \neq \pi_{5} \neq 0 \neq$ ). Pesaran et al. (2001) provide lower and upper critical bounds for the F-test. If the calculated F-statistic exceeds the upper bound then the null hypothesis of no cointegration among the variables in the MDF can be rejected. If the calculated F-statistics fall below the lower bound, the null hypothesis of no long-run relationship cannot be rejected.

The next step involves estimation of the long-run coefficients in the ARDL model with optimal lags. The selection criteria for the optimal lags, such as the Schwarz Bayesian Criterion (SBC) and the Akaike Information Criterion (AIC), are mostly used to determine the order of the ARDL model. The next step is to then estimate the short-run parameters for $E C M_{t-1}$. To ensure the convergence of the dynamics to the long-run equilibrium the sign of the lagged error correction coefficient $E C M_{t-1}$ must be negative and significant. The diagnostic tests comprise further testing for serial correlation, functional form, normality, and heteroscedasticity (Pesaran and Pesaran 2009). In addition, in order to test the stability of the MDF, the stability tests of Brown et al. (1975), also known as the cumulative sum (CUSUM) and the cumulative sum of squares (CUSUMSQ) tests based on the recursive regression residuals, are used. ${ }^{9}$

Once there is evidence that the variables are cointegrated, the direction of causality between the variables can be detected by applying the vector error correction method (VECM) Granger causality framework. Engle and Granger (1987) argued that inclusion of an error correction term could avoid the bias and determine the long-run causal relationship.

9 The CUSUM and CUSUMSQ statistics are updated recursively and plotted again the break points of the model. Providing that the plot of these statistics fall inside the critical 5 percent significance bounds, one can assume that the coefficients of a given regression are stable. 
Table 2. Perron unit root test

\begin{tabular}{|c|c|c|c|c|}
\hline \multirow[b]{2}{*}{ Variable } & \multicolumn{2}{|l|}{ At level } & \multicolumn{2}{|c|}{ At first difference } \\
\hline & t-statistic & Time break & t-statistic & Time break \\
\hline$M^{\prime} N_{t}$ & -1.2757 & 2009Q1 & $-12.2894^{*}$ & 1999:Q2 \\
\hline$G D P_{t}$ & -2.1164 & 1997Q4 & $-5.1315^{* * *}$ & 1997:Q4 \\
\hline$E X C_{t}$ & -2.0915 & 2001Q1 & $-10.4846^{*}$ & 1999:Q2 \\
\hline$D R U S_{t}$ & -3.1281 & 2002Q4 & $-8.1857^{*}$ & 1999:Q2 \\
\hline$D R K_{t}$ & -3.8496 & 2004Q4 & $-10.8221^{*}$ & 1999:Q2 \\
\hline
\end{tabular}

Note: * and ${ }^{* * *}$ represent significance at the 1 and 10 percent levels.

The VECM is as follows:

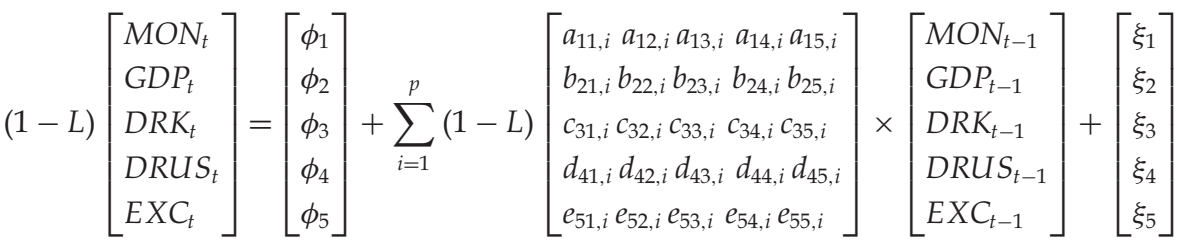

$$
\begin{aligned}
& \times\left[\begin{array}{l}
\operatorname{MON}_{t-1} \\
\mathrm{GDP}_{t-1} \\
\mathrm{DRK}_{t-1} \\
\operatorname{DRUS}_{t-1} \\
E C_{t-1}
\end{array}\right] \times\left[\mathrm{ECM}_{t-1}\right]+\left[\begin{array}{l}
\mu_{1 t} \\
\mu_{2 t} \\
\mu_{3 t} \\
\mu_{4 t} \\
\mu_{5 t}
\end{array}\right]
\end{aligned}
$$

where the difference operator is $(1-L)$ and the $E C M_{t-1}$ is the error correction term generated from the long-run relationship. Long-run causality is indicated by the significance of the coefficient for the $E C M_{t-1}$ using the t-test statistic. Short-run causality is indicated by the statistical significance of the F-statistic using a Wald test incorporating differences and lagged differences of the independent variables in the model.

\section{Empirical results}

The Perron unit-root test indicates that each of the variables are I(1), which confirms that the F-test is applicable (see Table 2). The Perron unit-root test indicates the existence of a structural break in 1999:Q2 pertaining to the AFC. The F-test results are sensitive to the number of lags set for each first-difference variable in the equation (see Bahmani-Oskooee and Goswami 2004; Bahmani-Oskooee and Nasir 2004). Based on results obtained from the $\mathrm{SBC}^{10}$ the optimal lag order is found to be two. ${ }^{11}$

10 Pesaran and Shin (1999) argue that the SBC-based ARDL model performs better than the AICbased model.

11 We set the maximum lag order up to five to ensure a sufficient degree of freedom for the econometric analysis because the sample size is quite small. 
Table 3. F-statistics for the cointegrating relationship

\begin{tabular}{lll}
\hline ARDL (1,0,1,1,2) & & \\
\hline Variable & $\mathbf{M O N}_{\boldsymbol{t}}$ & \\
\hline F-statistics & 3.5212 & \\
Critical values & $5 \%$ level & $10 \%$ level \\
Lower bounds & 3.0251 & 2.5590 \\
Upper bounds & 4.2084 & 3.6462 \\
Diagnostic tests & & \\
$\quad R^{2}$ & 0.9925 & \\
$\quad$ Adj- ${ }^{2}$ & 0.9914 & \\
$\quad$ Durbin-Watson & 2.0197 & \\
\hline
\end{tabular}

Table 4. The long-run and short-run ARDL model results

\begin{tabular}{lll}
\hline Dependent variable $=\mathbf{M O N}_{t}$ & \\
\hline Long-run results & Coefficient & t-statistic \\
Variable & -4.5345 & $-4.7923^{*}$ \\
\hline Constant & 2.0314 & $10.2810^{*}$ \\
$G D P_{t}$ & -0.1457 & $-3.6876^{*}$ \\
$E X C_{t}$ & 0.0623 & 1.4052 \\
$D R S_{t}$ & -0.2169 & -1.5507 \\
$D R K_{t}$ & -0.0556 & -0.6453 \\
DD & & \\
\hline Short-run results & Coefficient & t-statistic \\
Variable & 0.6782 & $3.3956^{*}$ \\
\hline$\Delta G D P_{t}$ & 0.2789 & $3.8560^{*}$ \\
$\Delta E X C_{t}$ & -0.1240 & $-2.6355^{*}$ \\
$\Delta D R U S_{t}$ & -0.0667 & -1.1870 \\
$\Delta D R K_{t}$ & -0.0185 & -0.6484 \\
DD & -0.3338 & $-4.0879^{*}$ \\
$E C M_{t-1}$ & & \\
Diagnostic tests & $\mathrm{LM} \mathrm{Version}$ & $\mathrm{F} \mathrm{Version}$ \\
Test statistic & $\chi^{2}(4)=6.1119$ & $\mathrm{~F}(4,63)=1.3390$ \\
$\quad$ Serial correlation & $\chi^{2}(1)=7.7316^{*}$ & $\mathrm{~F}(1,66)=7.2620^{*}$ \\
Functional form & $\chi^{2}(2)=0.6801$ & $\mathrm{Not}$ applicable \\
Normality & $\chi^{2}(1)=2.0072$ & $\mathrm{~F}(1,76)=2.0074$ \\
\hline Heteroscedasticity & & \\
\hline
\end{tabular}

Note: * significant at the 1 percent level.

Table 3 presents the computed F-value obtained in testing for the existence of a long-run relationship. When $M O N_{t}$ is the dependent variable, and its explanatory variable used in the model. The $\left(\mathrm{F}_{\mathrm{MON}} \mathrm{MON}_{t} \mid G D P_{t}, D R K_{t}, \mathrm{DRUS}, E X C_{t}\right)=3.52$, which is between the lower bound and upper bound at the 95 percent critical value. These values suggest that the cointegration relationship between money demand and its determinants is inconclusive. Therefore, it is important to test the significant negative lagged error-correction term in order to judge the existence of a cointegrating relationship (Bahmani-Oskooee 2001).

Table 4 shows the long-run and short-run coefficient estimates. $E C M_{t-1}$ has a negative sign and is significant, confirming the presence of a cointegrating relationship among $M O N_{t}$ 
and its determinants. ${ }^{12}$ The coefficient -0.33 shows that approximately 33 percent of the previous year's discrepancy between the actual and the equilibrium value of $M O N_{t}$ is corrected in each year. ${ }^{13}$ In the long run equation, real income $G D P_{t}$ and $E X C_{t}$ are significant but both interest rates are not significant (Table 4). Real income and the exchange rate play an important role in explaining long-run money demand $M O N_{t}$. The exchange rate coefficient has a negative sign, which supports the argument of Bahmani-Oskooee and Poorheydarian (1990). The negative sign of the nominal exchange rate coefficient indicates that depreciation of domestic currency (kip) creates the expectation of a further depreciation and then leads to an increase in holdings of foreign currency and a smaller holding of (demand for) domestic currency $M O N_{t} \cdot{ }^{14}$ Both the domestic and foreign interest rates do not significantly determine the long-run $M O N_{t} .{ }^{15}$ The main reason for this is that domestic interest rates are controlled by the monetary authority, which does not reflect the market mechanism (Kyophilavong 2010). There is an interest rate offered on domestic currency deposits and on foreign currency deposits in Laos. If there is a difference in the spread between these interest rates, it will trigger currency substitution.

In the short run, real income, the exchange rate, and the foreign interest rate $\left(G D P_{t}, E X C_{t}\right.$, $\left.D R U S_{t}\right)$ are significant determinants of money demand $M O N_{t}$ but the domestic interest rate $\left(D R K_{t}\right)$ is not significant (Table 4$)$. The foreign interest rate seems to be a better choice than domestic interest rate. As the result, higher foreign interest rate results in reduced demand for the domestic currency (domestic money demand).

Table 4 also presents the diagnostic tests associated with estimation of the equations. Results from the tests suggest that residuals are free from serial correlation, heteroscedasticity, and non-normality at the 5 percent level. ${ }^{16}$ The results imply that our underlying assumptions hold. The existence of a cointegrating relationship derived from equation 2 does not necessarily imply that the estimated coefficients are stable, an argument that BahmaniOskooee and Brooks (1999) make. Therefore, we use the CUSUM and CUSUMSQ tests developed by Brown et al. (1975) to test for the consistency of the long-run parameters. The CUSUM and CUSUMSQ tests show the plot of the CUSUM and CUSUMSQ statistics. The

12 Kremers et al. (1992) and Bahmani-Oskooee (2001) argue that a significant lagged error correction term $E C M_{t-1}$ is a relatively more efficient way to establish cointegration.

13 This result is consistence with Bahmani-Oskooee and Wang (2007) and Baharumshah et al. (2009), who find that the ECM of the money supply M2 is around -0.28 and -0.29 in China, respectively.

14 Our results are in opposition to those found by other scholars who argue that a depreciation of the exchange rate could increase money demand, such as reported by Tang (2007) for Singapore, Akinlo (2006) for Nigeria, and Adam and Goujon (2004) for Vietnam.

15 Bahmani-Oskooee and Karacal (2006) also found that the domestic interest rate was not significant in the money demand function for Turkey, and Akinlo (2006) found the same result for Nigeria.

16 Though there are the functional form problems, this might not lead to bias in estimation (Shrestha and Chowdhury 2007). 
Table 5. VECM Granger causality analysis

\begin{tabular}{|c|c|c|c|c|c|c|}
\hline \multirow[b]{2}{*}{ Dependent variables } & \multicolumn{5}{|l|}{ Short run } & \multirow{2}{*}{$\frac{\text { Long run }}{\mathrm{ECM}_{\mathrm{t}-1}}$} \\
\hline & $\overline{\Delta \mathbf{M} 2_{\mathrm{t}-1}}$ & $\Delta \mathrm{GDP}_{\mathrm{t}-1}$ & $\Delta \mathrm{EXC}_{\mathrm{t}-1}$ & $\Delta$ DRUS $_{\mathrm{t}-1}$ & $\Delta \mathrm{DRK}_{\mathrm{t}-1}$ & \\
\hline$\Delta \mathrm{M} 2_{\mathrm{t}-1}$ & - & $\begin{array}{l}14.6312^{*} \\
{[0.0003]}\end{array}$ & $\begin{array}{c}0.9434 \\
{[0.3346]}\end{array}$ & $\begin{array}{c}1.1371 \\
{[0.2898]}\end{array}$ & $\begin{array}{c}1.5331 \\
{[0.2197]}\end{array}$ & $\begin{array}{c}-0.4645^{*} \\
{[0.0000]}\end{array}$ \\
\hline$\Delta \mathrm{GDP}_{\mathrm{t}-1}$ & $\begin{array}{r}3725.2730^{*} \\
{[0.0000]}\end{array}$ & - & $\begin{array}{r}4221.5000^{*} \\
{[0.0000]}\end{array}$ & $\begin{array}{r}4306.8960^{*} \\
{[0.0000]}\end{array}$ & $\begin{array}{r}4377.6750^{*} \\
{[0.0000]}\end{array}$ & $\begin{array}{c}-0.0065 \\
{[0.3395]}\end{array}$ \\
\hline$\Delta \mathrm{EXC}_{\mathrm{t}-1}$ & $\begin{array}{c}10.9820^{*} \\
{[0.0014]}\end{array}$ & $\begin{array}{l}3.0707^{* * *} \\
{[0.0840]}\end{array}$ & - & $\begin{array}{c}11.8725^{*} \\
{[0.0010]}\end{array}$ & $\begin{array}{c}1.2507 \\
{[0.2671]}\end{array}$ & $\begin{array}{c}-0.0501^{\star \star * *} \\
{[0.0842]}\end{array}$ \\
\hline$\Delta$ DRUS $_{\mathrm{t}-1}$ & $\begin{array}{c}1.6517 \\
{[0.2028]}\end{array}$ & $\begin{array}{c}0.2299 \\
{[0.6330]}\end{array}$ & $\begin{array}{c}0.7042 \\
{[0.4041]}\end{array}$ & - & $\begin{array}{c}2.2988 \\
{[0.1339]}\end{array}$ & $\begin{array}{c}-0.0574 \\
{[0.2169]}\end{array}$ \\
\hline$\Delta \mathrm{DRK}_{\mathrm{t}-1}$ & $\begin{array}{c}0.0971 \\
{[0.7562]}\end{array}$ & $\begin{array}{c}1.2659 \\
{[0.2643]}\end{array}$ & $\begin{array}{c}0.3909 \\
{[0.5338]}\end{array}$ & $\begin{array}{c}0.8615 \\
{[0.3564]}\end{array}$ & - & $\begin{array}{c}-0.2306^{\star * *} \\
{[0.0111]}\end{array}$ \\
\hline
\end{tabular}

Note: *** and ${ }^{* * *}$ represent significance at the 1,5 and 10 percent levels respectively.

The $p$ value is shown in brackets.

statistics stay within the critical bounds, which confirms that the money demand equation $M O N_{t}$ is stable. This finding supports the McKinnon hypothesis (McKinnon et al. 1984) that money demand, in a country such as Laos, is stable if fluctuations of the exchange rate are taken into consideration.

Table 5 provides the Granger causality test results in the VECM framework. It shows that estimates of $E C M_{t-1}$ are statistically significant in the money demand equation $M O N_{t}$, exchange rate equation $E X C_{t}$, and domestic interest rate equation $D R K_{t}$. The long-run causality test results show that there is a bidirectional causality between money demand $M O N_{t}$ and the exchange rate $E X C_{t}$ and the domestic interest rate $D R K_{t}$. This implies that the exchange rate and domestic currency deposit interest rate play an important role in determining money demand $M O N_{t}$. On the other hand, money demand $M O N_{t}$ also has a feedback effect between the domestic currency deposit interest rate $D R K_{t}$ and exchange rate $E X C_{t}$. In addition, unidirectional causality also exists, running from real income $\left(G D P_{t}\right)$ to the foreign currency deposit interest rate $\left(D R U S_{t}\right)$ to money demand $\left(M O N_{t}\right)$. And the real income $\left(G D P_{t}\right)$ and the foreign currency deposit interest rate $\left(D R U S_{t}\right)$ Granger cause the exchange rate $\left(E X C_{t}\right)$. It implies that real income $\left(G D P_{t}\right)$ and the foreign currency deposit interest rate $\left(D R U S_{t}\right)$ play important roles in determining money demand $M O N_{t}$.

The short run causality test shows that bidirectional causality exists between real income $\left(G D P_{t}\right)$ and money demand $\left(M O N_{t}\right)$ (see Table 3$)$. There is unidirectional causality running from the domestic currency deposit interest rate $\left(D R K_{t}\right)$ and the exchange rate $\left(E X C_{t}\right)$ to real income $\left(G D P_{t}\right)$. In addition, money demand $\left(M O N_{t}\right)$, real income $\left(G D P_{t}\right)$, and the foreign interest rate $\left(D R U S_{t}\right)$ Granger cause the exchange rate $E X C_{t}$.

\section{Conclusions and policy implications}

The estimation of a money demand function and identification of its stability is crucial to policymakers to formulate effective monetary policy, particularly in developing 
economies, but the empirical evidence on the latter is inconclusive. Despite many studies on the money demand function in several countries, there has been no significant contribution in the case of Laos. Therefore, this paper applies the ARDL approach - a relatively new cointegration technique in the presence of structural breaks - to investigate the stability of the money demand function and its determinants in Laos. Granger causality tests are also applied in the VECM framework to detect directional causality between variables. We find the existence of cointegration between real money demand, real income, foreign and domestic currency deposit interest rates, and the nominal exchange rate. Results from CUSUM and CUSUMSQ tests provide evidence to support the conclusion that the inclusion of the exchange rate in the money demand function make the latter stable and supports McKinnons's hypothesis (McKinnon et al. 1984) that money demand is stable if fluctuations in the exchange rate are considered.

Moreover, bidirectional causality exists between money demand and the exchange rate. As Laos is a dollarized economy, implementation of an effective monetary policy is rather difficult. Based on the results from this study, however, monetary policy will be more effective if the monetary authority takes into consideration fluctuations in the exchange rate. Therefore, the Lao monetary authority should pay more attention to attaining exchange rate stability. Moreover, the BoL faces numerous challenges pertaining to effectively managing an effective exchange rate policy.

Based on the key findings from this paper, several policy recommendations can be made. First, the Lao authorities need to increase foreign reserves to effectively manage the exchange rate. The BoL currently adopts a managed-floating-exchange-rate policy in order to make the kip stable against the U.S. dollar. Its foreign reserves are relatively small, however, accounting for 1 to 2 months of imports. It is important for the country to use its foreign reserves more effectively in terms of intervention in the foreign exchange market, and it is crucial to increase its foreign reserves.

Second, the BoL should improve its human resource capacity and decision process for exchange rate management. Improving human resources and the decision-making process for exchange rate management are important challenges facing the BoL (Kyophilavong 2010).

Third, the BoL needs to improve the instruments of monetary policy. The BoL has limited tools of monetary policy to control inflation and promote economic growth. Monetary policy instruments are mainly focused on direct controls such as interest rate controls and credit ceilings (Kyophilavong 2010). Therefore, it is crucial that the BoL develop the tools of monetary policy - especially in indirect instruments such as reserve requirements, open market operations, and overdraft facilities. 
Fourth, the BoL should make more efforts to reduce the importance of dollarization in the economy. Although the importance of dollarization has declined since 2000, the dollarization ratio is still high. A high degree of dollarization prevents the effective implementation of monetary and exchange rate policy in Laos. There are some constraints related to institutional, regulatory, and human resources to deal with dollarization in Laos (Kyophilavong 2010). Therefore, the strengthening of institutions, law enforcement, and human resources are also important elements to reduce dollarization in the short and long run (Kyophilavong et al. 2017).

Lastly, macroeconomic stability is important to increase the market confidence on government policy and macroeconomic management. Currently, the Lao economy is facing the macroeconomic instability arising from large budget deficits, high external debts, and low foreign reserves. The improvement of macroeconomic stability is the important key to exchange rate management and reduction of the impact of dollarization in the economy.

\section{References}

Adam, Christopher, and Michael Goujon. 2004. The Transactions Demand for Money in the Presence of Currency Substitution: Evidence from Vietnam. Applied Economics 36:1461-1470.

Akinlo, Enisan A. 2006. Stability of Money Demand in Nigeria: An Autoregressive Distributes Lag Approach. Journal of Policy Modelling 28:445-452.

Arango, Sebastian, and M. Ishaq Nadiri. 1981. Demand for Money in Open Economies. Journal of Money Economics 7:69-83.

Ariff, Mohamed, and Alireza Zarei. 2018. Sustainable Development and Currency Exchange Rate Behavior. Asian Economic Papers 17(3):148-173.

Baharumshah, Ahmad Zubaidi, Siti Hamizah Mohad, and A. M. Mansur Masih. 2009. The Stability of Money Demand in China: Evidence from the ARDL Approach. Economic Systems 33:231-244.

Bahmani-Oskooee, Mohsen. 2001. Nominal and Real Effective Exchange Rates of Middle Eastern Countries and Their Trade Performance. Applied Economics 33:103-111.

Bahmani-Oskooee, Mohsen, and Gour Gobinda Goswami. 2004. Exchange Rate Sensitivity of Japan Bilateral Trade Flows. Japan and the World Economy 16:1-15.

Bahmani-Oskooee, Mohsen, and Muge Karacal. 2006. The Demand for Money in Turkey and Currency Substitution. Applied Economics Letter 13:635-642.

Bahmani-Oskooee, Mohsen, and Mohammad Pourheydarian. 1990. Exchange Rate Sensitivity of the Demand for Money and Effectiveness of Fiscal and Monetary Policies. Applied Economics 22:917-925.

Bahmani-Oskooee, Mohsen, and Hafez Rehman. 2005. Stability of the Money Demand Function in Asian Developing Countries. Applied Economics 37:773-792.

Bahmani-Oskooee, Mohsen, and Yongqing Wang. 2007. How Stable is the Money Demand Function in China? Journal of Economic Development 23(1):21-33.

Baliño, T. J. Tomas, Adam Bennett, and Eduardo Borensztein. 1999. Monetary Policy in Dollarized Economies. IMF Occasional Paper No. 171. Washington, DC: International Monetary Fund. 
Baum, Christopher F. 2004. A Review of Stata 8.1 and its Time Series Capabilities. International Journal of Foresting 20(1):151-161.

Berg, Andrew, and Eduardo Borensztein. 2000. The Choice of Exchange Rate Regime and Monetary Target in Highly Dollarized Economies. Journal of Applied Economics 3:285-324.

BoL (Bank of Lao PDR). 2010. Annual Economic Report 2010. Vientiane: The Bank of Lao PDR.

Bank of the Lao PDR (BoL), World Bank (WB), and Asian Development Bank (ADB). 2002. The Banking and Financial Sector of Lao PDR. Financial Sector Note. Vientiane: Lao PDR.

Bourdet, Yves. 1992. Macroeconomic Stabilisation Under Transition in Laos. Communist Economies and Economic Transformation 4(4):537-555.

Brown, R. L., J. Durbin, and M. Evans. 1975. Techniques for Testing the Constancy of Regression Relations Over Time. Journal of the Royal Statistical Society 37:149-163.

Chaisrisawatsuk, S., Subhash C. Sharma, and Abdur R. Chowdhury. 2004. Money Demand Stability Under Currency Substitution: Some Recent Evidence. Applied Financial Economics 14:19-27.

Cuddington, John T. 1983. Currency Substitution, Capital Mobility and Money Demand. Journal of International Money and Finance 2(2):111-133.

Darrat, Ali F., and Ahmed Al-Mutawaa. 1996. Modelling Money Demand in the United Arab Emirates. Quarterly Review of Economics and Finance 36:65-87.

Dekle, Robert, and Madmood Pradhan. 1999. Financial Liberalization and Money Demand in the ASEAN Countries. International Journal of Finance and Economics, 14:205-215.

Elliot, Granham, Thomas. J. Rothenberg, and James H. Stock, 1996. Efficient Tests for an Autoregressive Unit Root. Econometrica 64:813-836.

Engle, Robert F., and C. W. J. Granger. 1987. Cointegration and Error Correction Representation: Estimation and Testing. Econometrica 55(2):251-276.

Ericsson, Reil. 1998. Empirical Modeling of Money Demand. Empirical Economics 23:295-315.

Gochoco-Bautista, Maria Socorro. 2006. An Assessment of the Usefulness of Money for Policy in the Philippines. Asian Economic Papers 5(1):142-176.

Gochoco-Bautista, Maria Socorro. 2009. Asset Price Booms, "Fat Tails," and Monetary Policy in East Asia. Asian Economic Papers 5(1):69-98.

Johansen, Soren, and Katarina Juselius. 1990. Maximum Likelihood Estimation and Inference on Cointegration with Application to the Demand for Money. Oxford Bulletin of Economics and Statistics 52:169-210.

Judd, John P., and John. L. Scadding. 1982. The Search for a Stable Money Demand Function: A Survey of the Post-1973 Literature. Journal of Economic Literature XX:993-1023.

Keovongvichith, Phetsathaphone. 2004. Dollarization in Laos: Evidence, Causes and Policy Implications. Paper presented at the Third International Conference of the Japan Economic Policy Association, Meiji University, Tokyo, Japan, 13-14 November.

Kyophilavong, Phouphet. 2010. Lao Peoples Democratic Republic: Dealing with Multi Currencies. In: Dealing with Multiple Currencies in Transitional Economies, edited by G. Capannelli and J. Menon, pp. 99-131. Manila: Asian Development Bank. 
Kyophilavong, Phouphet. 2016. Mining Booms and Growth in Laos-Empirical Result from a CGE Model. International Journal of Development Issues 15(1):51-61.

Kyophilavong, Phouphet, Muhammad Shahbaz, and Gazi Salah Uddin. 2013. Does J-Curve Phenomenon Exist in Case of Laos? An ARDL Approach. Economic Modelling 35:833-839.

Kyophilavong, Phouphet, Aviral K. Tiwari, Byongki Kim, and Saysamone Phoyduangsy. 2017. The Causality of Dollarisation, Interest Rate and Exchange Rate: Evidence from Laos. Global Business and Economics Review 19(2):115-125.

Kyophilavong, Phouphet, and Toshihisa Toyoda. 2008. Foreign Capital Inflows in the Natural Resources Sectors: Impacts on the Lao Economy. Paper presented at the Future of Economic Integration in Asia Conference, Bangkok, Thailand, 20-21 November.

Kyophilavong, Phouphet, Gazi S. Uddin, and Muhammad Shahbaz. 2016. The Nexus Between Financial Development and Economic Growth in Lao PDR. Global Business Review 17(2):303-317.

Lao Statistics Bureau (LSB) and World Bank (WB). 2014. Poverty Profile in Lao PDR: Poverty Report for the Lao Consumption and Expenditure Survey (2012-2013). Vientiane: Lao Statistics Bureau (LSB) and World Bank (WB).

Layson, Stephen. 1983. Homicide and Deterrence: Another View of the Canadian Time-Series Evidence. Canadian Journal of Economics 16(1):52-73.

Lutkepohl, Helmut. 1982. Non-causality Due to Omitted Variables. Journal of Econometrics 19:367-378.

McKinnon, Ronald I., Christopher Radclipfe, Kong-Yam Tan, Arthur D. Warga, and Thomas D. Willett. 1984. International Influence on the U.S. Economy: Summary of an Exchange. American Economic Review 74:1132-1134.

Menon, Jayant. 2006. Would You Like to Pay in Dollars, Baht, or Kip? Economic Consequences of Multiple Currencies in the Lao Peoples Democratic Republic. Journal of Greater Mekong Subregion Development Studies 3(2):35-47.

Menon, Jayant. 2008. Dealing with Multiple Currencies: What Options for the Transitional Economies of Southeast Asia? Journal of the Asia Pacific Economy 13(2):131-146.

Ng, Serena, and Pierre Perron. 2001. Lag Length Selection and the Construction of Unit Root Test with Good Size and Power. Econometrica 69:1519-1554.

Oomes, Nienke, and Franziska Ohnsorge. 2005. Money Demand and Inflation in Dollarized Economies: The Case of Russia. Journal of Comparative Economics 33:462-483.

Otani, Ichiro, and Chi Do Pham. 1996. The Lao Peoples Democratic Republic: Systemic Transformation and Adjustment. IMF Occasional Paper No. 137. Washington, DC: International Monetary Fund.

Ouattara, Bazoumana. 2004. Modelling the Long-run Determinants of Private Investment in Senegal. The School of Economics Discussion Paper Series No. 0413, Economics Department, The University of Manchester.

Perron, Pierre. 1997. Further Evidence on Breaking Trend Functions in Macroeconomic Variables. Journal of Econometrics 80(2):355-385.

Pesaran, Bahram, and Hashem Pesaran. 2009. Time Series Econometrics: Using Microfit 5.0. Oxford: Oxford University Press.

Pesaran, M. Hashem, and Yongcheol Shin. 1999. An Autoregressive Distributed Lag Modeling Approach to Cointegration Analysis. In: Econometrics and Economic Theory in the 20th Century: The Ragnar 
Frisch Centennial Symposium, edited by S. Strom, A. Holly, and P. Diamond, pp. 371-413. Cambridge: University Press.

Pesaran, M. Hashem, Yongcheol Shin, and J. Richard Smith. 2001. Bounds Testing Approaches to the Analysis of Level Relationships. Journal of Applied Economics 16:289-326.

Schnabl, Gunther. 2015. Monetary Policy and Structural Decline: Lessons from Japan for the European Crisis. Asian Economic Papers 14(1):124-150.

Shrestha, Min B., and Khorshed Chowdhury. 2007. Testing Financial Liberalization Hypothesis with ARDL Modeling Approach. Applied Financial Economics 17(8):1529-1540.

Siddiki, Jalal U. 2000. Demand for Money in Bangladesh: A Cointegration Analysis. Applied Economics 32:1977-1984.

Tang, Tuck Cheong. 2007. Money Demand Function for Southeast Asian Countries: An Empirical View from Expenditure Components. Journal of Economic Studies 34(6):476-496.

Toyoda, Toshihisa, and Phouphet Kyophilavong. 2005. Savings and Assets of Urban Households in the Lao PDR. In: Towards a Market Economy Under One Party System in the Lao PDR, edited by N. Amakawa and N. Yamada, pp. 155-180 [in Japanese]. Kenkyu Sosho (IDE Research Series) No. 545. Institute of Developing Economies, Japan.

Willett, Thomas D., Ekniti Nitithanprapas, Isriya Nitithanprapas, and Sunil Rongala. 2004. The Asian Crises Reexamined. Asian Economic Papers 3(3):32-87.

Wu, Chung-Shu, Jung-Lin Lin, George C. Tiao, and David C. Cho. 2005. Is Money Demand in Taiwan Stable? Economic Modelling 22(3):327-346. 